\title{
Juventude, homossexualidade e diversidade: um estudo sobre o processo de sair do armário usando mapas corporais ${ }^{1}$
}

\author{
Aryel Ken Murasaki ${ }^{a}$, Sandra Maria Galheigo ${ }^{\mathrm{b}}$ \\ aServiço de Atendimento Especializado - SAE, Cidade Líder II em DST, HIV/AIDS, \\ Hospital Prof Dr Waldomiro de Paula São Paulo, Itaquera, SP, Brasil.

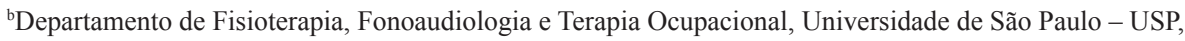 \\ São Paulo, SP, Brasil.
}

\begin{abstract}
Resumo: Esta pesquisa objetivou estudar as percepções e representações de jovens sobre o processo de assumir sua homossexualidade e sobre os impactos em seu cotidiano, no que tange à autonomia, inclusão e participação social. Ademais, buscou conhecer fatores facilitadores, obstáculos e estratégias utilizadas. A pesquisa consistiu em um estudo exploratório de caráter qualitativo com dois jovens gays e duas jovens lésbicas entre 18 e 24 anos, por meio da técnica de mapas corporais narrados, que são imagens do corpo em tamanho real, criadas a partir do desenho e pintura complementadas por narrativas orais. A análise de conteúdo identificou três categorias temáticas centrais: (a) Preconceito, Estigma e Empoderamento: compreende as representações sociais da homossexualidade e sobre como os processos de resistência e empoderamento operam; (b) Discriminação, Isolamento e Participação Social: refere -se às percepções sobre como o processo de sair do armário afeta o cotidiano, principalmente nos espaços familiar, escolar, do trabalho e de convivência social e cultural; (c) Possibilidades de Transformação e Projetualidade: sintetiza as expectativas e visões de futuro dos participantes para suas vidas e para a transformação da sociedade, em termos do respeito à diversidade sexual. Conclui-se que os discursos vigentes em torno da homossexualidade permeiam as falas dos participantes, principalmente nos assuntos ligados ao preconceito e discriminação à população LGBT no Brasil. É relevante destacar a importância da rede social próxima para o processo de sair do armário.
\end{abstract}

Palavras-chave: Juventude, Homossexualidade, Diversidade Sexual.

\section{Youth, homossexuality and diversity: a study on the process of 'coming out of the closet' using body-maps}

\begin{abstract}
This research aimed to study the perceptions and representations of young people on the process of coming out of the closet and the impacts on their daily lives regarding autonomy, inclusion and social participation. Moreover, it sought to know facilitating factors, obstacles and strategies used. The research consisted of an exploratory qualitative study with 2 gay and 2 lesbian youth between 18 and 24 years through body map storytelling method, which consists of life-size human body images created through drawing and painting and, complemented by oral narratives. The content analysis identified three central themes: (a) Prejudice, Stigma and Empowerment and comprises the social representations of homosexuality and how processes of resistance and empowerment operate; (B) Discrimination, Isolation and Social Participation refers to perceptions on how the process of coming out of the closet affects the daily life, particularly in family, school, work and social/cultural contexts; (C) Opportunities to change and life projects development summarizes expectations and visions of future for their lives and the transformation of society in terms of respect for sexual diversity. In conclusion, the current discourses on homosexuality permeate the participants' sayings, especially on issues related to prejudice and discrimination to the LGBT population in Brazil. It is worth highlighting the importance of a close social network to the process of coming out.
\end{abstract}

Keywords: Youth, Homosexuality, Sexual Diversity.

Autor para correspondência: Aryel Ken Murasaki, Departamento de Fisioterapia, Fonoaudiologia e Terapia Ocupacional, Universidade de São Paulo, Rua Cipotânea, 51, Cidade Universitária, CEP 05360-000, São Paulo, SP, Brasil, e-mail: aryel.km@gmail.com

Recebido em Abr. 28, 2015; 1ª Revisão em Jul. 24, 2015; Aceito em Out. 30, 2015. 


\section{Introdução}

Compreender o processo de se assumir homossexual e seus impactos no cotidiano de jovens remete à discussão de como as referências normativas para a sexualidade são produzidas social e culturalmente, e são influenciadas por questôes de gênero, idade, escolaridade e renda. Segundo Rodrigues (1983), os sexos possuem

[...] um status social cujos limites, direitos e obrigaçôes estão devidamente convencionados e em relação aos quais a comunidade mostra determinadas expectativas (RODRIGUES, 1983, p. 70).

Essas práticas discursivas e não discursivas em torno do sexo, conforme aponta Foucault (1988), foram se constituindo desde o século XVIII em um dispositivo de poder que buscava produzir discursos de verdade, bem como sua normalizaçáo e controle. Não só falou muito e forçou todo mundo a falar dele [o sexo], como também empreendeu a formulação de sua verdade regulada (FOUCAULT, 1988, p. 68).

A homossexualidade é assim uma concepção da segunda metade do século XIX, quando a prática é nomeada, passando a ser caracterizada como desviante da norma, o que demanda "toda uma série de intervençôes e controles novos" (FOUCAULT, 1992, p. 233). Fry e Macrae (1991) discutem que essa preocupação em relação às práticas homossexuais acabou criando taxonomias no intuito de defini-las e classificá-las como "entes específicos", reconhecidos não só através de um comportamento característico, mas também por traços fisionômicos, peculiaridades hormonais e desempenhos.

O problema é que a homossexualidade é uma infinita variação sobre o mesmo tema: o das relaçóes sexuais e afetivas entre pessoas do mesmo sexo. Assim, ela é uma coisa na Grécia Antiga, outra coisa na Europa do fim do século XIX, outra coisa ainda entre os índios Guaiaqui do Paraguai (FRY; MACRAE, 1991, p. 7).

Em suma, a sexualidade desenvolve-se permeada por construçôes sociais, históricas e culturais. A heterossexualidade é concebida como natural e norma, e, consequentemente, as outras formas de sexualidade são constituídas como antinaturais, peculiares e anormais. Dentro dessas, inclui-se a homossexualidade, que, ao ser considerada transgressora de uma norma, pode ser alvo de estigma e preconceito (LOURO, 2000).
O estigma pode ser entendido como uma referência a um atributo pessoal profundamente depreciativo e está relacionado a categorizaçóes que a sociedade realiza acerca de suas referências de normalidade (GOFFMAN, 2008). Este autor divide os sujeitos estigmatizados em duas categorias: o desacreditado, que tem seu estigma visivelmente aparente; e o desacreditável, que possui um estigma que não está imediatamente aparente. Neste caso, o sujeito estigmatizado constantemente manipula as informaçôes acerca de seu estigma - ação denominada pelo autor de "encobrimento" (GOFFMAN, 2008).

É por meio do encobrimento que o estigmatizado, no caso o homossexual, esconde sua homossexualidade, recebendo e aceitando um tratamento baseado em falsas suposiçóes a seu respeito, com o intuito de não perturbar suas relaçôes sociais (NUNAN, 2007).

Com a intenção de evitar o desgaste pessoal causado pelo encobrimento, muitos optam por revelar-se voluntariamente, deixando de ser um indivíduo desacreditável para transformar-se em desacreditado. Em relação aos homossexuais, este ato tem sido nomeado atualmente de assumir-se ou sair do armário (NUNAN, 2007; SAGGESE, 2009).

Saggese (2009) afirma que o indivíduo, ao revelar sua homossexualidade, questiona valores e crenças arraigados na sociedade. Segundo o autor, esse é um processo complexo, permeado de valores culturais, que envolve uma série de negociaçóes de ordem simbólica e prática, realizadas no âmbito das relações interpessoais do sujeito. $\mathrm{O}$ modo que ele escolherá para ocultar ou revelar sua homossexualidade terá, necessariamente, repercussão direta em suas vivências, a partir da maneira pela qual ele será reconhecido enquanto ser social (SAGGESE, 2009).

Portanto, o ato de sair do armário envolve mais do que colocar-se publicamente como homossexual. Diz respeito a um processo político através do qual o indivíduo questiona a norma heterossexual, tornando-a visível e culturalmente inteligível (VIEIRA, 2008).

Assumir-se homossexual implica estar sujeito ao preconceito, entendido como atitudes hostis ou negativas baseadas em generalizações fundamentadas por estereótipos. Assim, aplica-se uma série de características a qualquer pessoa de um determinado grupo, independentemente das variaçôes individuais (NUNAN, 2003). Para o autor, muitas pessoas teriam preconceito contra homossexuais por acreditarem que este grupo apresenta um sistema de valores diferente (ou oposto) ao da cultura dominante. Nesse sentido, os homossexuais acabam por sofrer preconceito nos diversos contextos sociais em que estão inseridos, sejam a família, o trabalho e a escola (NUNAN, 2003). 
Para além da discussão do estigma e do preconceito, autores têm discutido em que medida há também discriminaçáo, e para tal têm utilizado o conceito de homofobia. Rios (2009) define homofobia como o preconceito e discriminação perpetrados contra homossexuais, bissexuais, travestis e transexuais.

Muitas vezes a discriminação é fruto de medidas, decisões e práticas aparentemente neutras, desprovidas de justificação e de vontade de discriminar, cujos resultados, no entanto, têm impacto diferenciado perante diversos indivíduos e grupos, gerando e fomentando preconceitos e estereótipos inadmissíveis (RIOS, 2009, p. 76).

Rios (2009) também aponta que existem duas vertentes de entendimento da homofobia: a homofobia como aversão fóbica e a homofobia como heterossexismo. Na primeira, homofobia estaria relacionada à rejeição ou à aversão ao homossexual ou à homossexualidade, com foco em seu caráter individual (RIOS, 2009). Uma hipótese dessa perspectiva seria a de que:

[...] reaçôes homofóbicas violentas provêm de sujeitos em grave conflito interno com suas próprias tendências homossexuais, resultantes da projeçáo de um sentimento insuportável de identificação inconsciente com a homossexualidade, donde a intolerância à homossexualidade (RIOS, 2009, p. 62).

$\mathrm{Na}$ segunda vertente, a homofobia seria "[...] um sistema em que a heterossexualidade é institucionalizada como norma social, política, econômica e jurídica” (RIOS, 2009, p. 62). Assim, aqueles que estão dentro do padrão possuiriam privilégios e seriam superiores, enquanto os outros sofreriam processos de opressão e prejuízo. O binômio heterossexualidade/homossexualidade seria um "[...] critério distintivo para o reconhecimento da dignidade dos sujeitos e para a distribuição dos benefícios sociais, políticos e econômicos" (RIOS, 2009, p. 63).

Aqueles que fogem aos padrôes heterossexuais estão sujeitos à discriminação, ou seja, quando:

[...] distinções, exclusões, restrições ou preferências anulam ou prejudicam o reconhecimento, o gozo ou o exercício em pé de igualdade de direitos humanos e liberdades fundamentais nos campos econômico, social, cultural ou em qualquer campo da vida pública (RIOS, 2009, p. 73).

Com base nas ideias apresentadas, consideramos que a questão do assumir-se homossexual influencia o modo como se estrutura a vida dos sujeitos, visto que tal processo pressupóe a instauração de uma nova identidade carregada de estereótipos e elementos estigmatizantes.

Sair do Armário é uma etapa importante para a autonomia do sujeito e sua participação social, bem como para o desenvolvimento de um sentimento positivo a respeito da própria homossexualidade, inclusive como forma de enfrentamento do preconceito.

Todavia, o sujeito não assume uma identidade homossexual dada; esta é construída ao longo de sua vida, principalmente na fase da adolescência quando as identidades sexuais são mais bem consolidadas (ISAY, 1998). Além disso, assumir-se homossexual implica uma

[...] convergência de desejos, de sentimentos, de práticas e de consciência, que culminam em uma definição e aceitação de si como homossexual (CASTAÑEDA, 2007, p. 52).

Contudo, cabe aqui salientar que os homossexuais nunca estarão totalmente assumidos, já que a cada encontro com novas pessoas será preciso realizar "[...] novos levantamentos, novos cálculos, novos esquemas e demandas de sigilo ou exposição" (SEDGWICK, 2007, p. 22). Como afirma Sedwick, o "armário homossexual" é uma "característica fundamental da vida social" (SEDGWICK, 2007, p. 22), e existem poucos homossexuais que não o têm como uma "presença formadora".

A orientação sexual permeia as atividades e cotidianos dos sujeitos. Assim, sua autonomia e participação social podem vir a ser constrangidas nos ambientes familiar, escolar, de trabalho, de lazer e convivência social. Sair do Armário pode diminuir o "poder contratual" dos sujeitos (SARACENO, 1999) e resultar em prejuízo no acesso e gozo aos direitos. Tal condição pode desencadear ou agravar processos de vulnerabilidade e desfiliação social (CASTEL, 1994). Segundo este autor, as situaçóes de vulnerabilidade social dizem respeito ao sujeito que, por diferentes determinantes, se encontra com inserção precária no mundo do trabalho e/ou fragilidade em sua sociabilidade familiar e inserção social. Já as situaçōes de desfiliação são configuradas quando há uma conjunção entre ausência de trabalho e isolamento social, resultando numa ruptura das redes sociais de suporte (CASTEL, 1994). Conhecer os impactos de assumir uma orientação sexual diferente da norma pode favorecer a melhor compreensão desses processos e contribuir para a construção de açóes emancipatórias.

Esta pesquisa objetivou estudar as percepçôes e representaçôes de jovens sobre o processo de assumir sua homossexualidade e sobre os impactos em seu 
cotidiano, no que tange à autonomia, inclusão e participação social. Ademais, buscou conhecer quais são os fatores que consideram ter facilitado ou dificultado tal processo, bem como as estratégias utilizadas para este fim. Finalmente, o estudo se propôs refletir sobre como as narrativas dos jovens participantes da pesquisa remetem a ideias que são produzidas social e culturalmente.

\section{Metodologia}

A pesquisa consistiu em um estudo exploratório de caráter qualitativo com 2 jovens gays e 2 jovens lésbicas entre 18 e 24 anos. Optou-se por essa faixa etária de jovens-jovens considerando que esses já possuem um processo de elaboração sobre o assumir-se gay/lésbica iniciado, não estando no início desse processo (adolescentes-jovens) e não o tendo consolidado (jovens adultos) ${ }^{2}$. Os jovens foram recrutados no Projeto Purpurina, ligado a uma organização não governamental do município de São Paulo que realiza acolhimento, suporte e grupos de discussão com jovens lésbicas, gays, bissexuais, travestis, transexuais e transgêneros (LGBT).

A pesquisa fez uso da técnica nomeada de mapa corporal narrado (body map storytelling) (GASTALDO et al., 2012; GASTALDO; MAGALHÃES; CARRASCO, 2013). A técnica do mapeamento corporal (body-mapping) foi inicialmente utilizada em práticas terapêuticas com mulheres com HIV/AIDS na África do Sul como processo de elaboraçáo da morte e de construção de memórias para seus filhos. Posteriormente, a técnica foi usada para contar histórias sobre a convivência com a HIV/AIDS e a esperança com o tratamento com antirretrovirais, resultando no livro Long Life, Positive HIV Stories (SOLOMON, 2007). O mapeamento corporal se transformou assim em ferramenta para contar histórias de vida (SOLOMON, 2007), e para a produção de narrativas sobre o adoecimento e as condiçōes de vida (DEVINE, 2008). Mais recentemente, a técnica começou a ser usada, no âmbito das metodologias visuais, em pesquisas que buscam incorporar outras formas de narrativas, principalmente quando o uso isolado de entrevistas mostra-se limitado (GASTALDO et al., 2012; GASTALDO; MAGALHÃES; CARRASCO, 2013; DAVY et al., 2014).

Nesta pesquisa, os participantes foram convidados a contar suas histórias acerca do processo de se assumirem gays e lésbicas, por meio da elaboração de um painel no qual cada um imprimiu sua forma corporal em tamanho real, adicionou símbolos expressivos em relação ao tema discutido e apresentou um lema escolhido para si e uma mensagem final. Os encontros foram gravados e transcritos, e os painéis foram fotografados, o que possibilitou a análise de conteúdo tanto das narrativas visuais como das orais.

A pesquisa foi aprovada pelo Comitê de Ética em Pesquisa da Faculdade de Medicina da Universidade de São Paulo sob o protocolo de pesquisa de número 145/11 em 13/05/2011. Os participantes assinaram o Termo de Consentimento Livre e Esclarecido e a autorização para uso de imagem dos desenhos produzidos.

Foram realizados três encontros, de aproximadamente uma hora e meia com cada participante, tendo sido utilizado um roteiro com questôes disparadoras. O primeiro encontro consistiu na apresentação e discussão da proposta e no início da elaboração dos painéis, com a temática do processo de descoberta de ser homossexual. No segundo encontro foram abordadas as percepções dos participantes sobre o processo de sair do armário e as repercussóes em suas relaçóes e cotidianos. O terceiro encontro teve como foco os elementos facilitadores e complicadores no processo de assumir a homossexualidade.

O pesquisador executante realizou um diário de campo, em que registrou as percepçóes do processo vivido em cada sessão, as experiências na utilização e manuseio da técnica e as reflexôes pessoais acerca de seu processo enquanto pesquisador.

O estudo das narrativas seguiu os passos metodológicos e o arcabouço teórico da hermenêutica-dialética, propostos por Minayo (1999). A fotografia digital dos painéis e o material transcrito foram estudados em sua temática e a partir da simbologia atribuída pelos participantes, buscando-se alcançar um maior aprofundamento dos conteúdos expressados e estabelecer relaçóes dialéticas entre os pressupostos teóricos e o material empírico revelado. As primeiras classificaçóes temáticas foram sendo refinadas em categorias e, posteriormente, reagrupadas em categorias centrais unificadoras.

O resultado final envolveu não apenas os participantes da pesquisa, mas também o pesquisador e sua reflexão sobre o tema. Na proposta hermenêutica-dialética deve-se considerar a construção do pensamento, seus caminhos e meios que fazem parte do processo de produção do conhecimento. Nesta perspectiva, a contextualização tanto do pesquisador como dos participantes se faz necessária, pela compreensão de que é preciso entender de quais lugares se fala, pois o grupo social a que se pertence, o tempo histórico e a formaçáo são elementos que podem influenciar o estudo (MINAYO, 1999). 
O pesquisador executante tem uma aproximação pessoal com o tema abordado. É um jovem homossexual, assumido desde sua adolescência, e que atua na organização não governamental na qual os jovens foram recrutados, auxiliando o enfrentamento desse processo na tentativa de diminuir o sofrimento por este causado. Enfrentou a trajetória de se assumir enquanto homossexual em diferentes contextos, o que possibilita uma maior aproximação de si com o tema.

Todos os jovens participantes possuem nível superior incompleto, estão assumidos para seus círculos mais próximos de relaçóes e no geral possuem relacionamentos satisfatórios, embora não isentos de conflito, com aqueles que sabem de sua orientação sexual. $O$ fato de os participantes integrarem discussões e reflexóes sobre o assumir-se homossexual resultou em uma participaçáo motivada e interessada. Portanto, tanto o pesquisador executante como os participantes compartilham o engajamento com a questão LGBT. Ademais, todos participam da vida social de São Paulo, onde o Projeto Purpurina se localiza, e por ser uma cidade cosmopolita está mais acostumada às discussóes e manifestações a favor da diversidade, mas que apresenta, ao mesmo tempo, episódios marcantes de homofobia em sua vida urbana.

O discurso final do trabalho, portanto, expressa um saber compartilhado do ponto de vista cultural, bem como um compromisso ético e político para com o respeito à diversidade.

\section{Resultados}

\subsection{Apresentação dos jovens e de seus painéis}

A exposição dos resultados se inicia pela apresentação dos jovens, seus painéis e elaboração, e suas histórias de vida. Nesta etapa, procurou-se garantir a forma e a coloquialidade com que se apresentaram, e oferecer um resumo de suas vivências mais relevantes de descoberta e revelação de sua homossexualidade, sua situação de vida atual e suas expectativas para o futuro, bem como os sentimentos envolvidos em todo o processo. Para a garantia do sigilo, seus nomes foram trocados e qualquer informação que possibilitasse sua identificação foi eliminada.

\subsubsection{Pedro}

Pedro é um jovem gay de 19 anos, estudante universitário e agente de prevenção de HIV/AIDS. Acha-se tímido e não gosta de ser o centro das atençôes. Conta que sempre soube que era "diferente dos outros garotos", mas que somente na puberdade considerou a hipótese de que poderia ser gay, já que não se interessava por meninas. Relata que desde pequeno seus interesses eram voltados para figuras masculinas e questionava se era "normal para um garoto heterossexual”. Na escola, era apontado como gay, recebia apelidos, sofria chacotas por seus gestos e modo de andar.

Com 16 anos, passa a querer experimentar sua sexualidade e ir a lugares de sociabilidade homossexual. Dá seu primeiro beijo e, a partir dessa experiência, vai constituindo sua identidade homossexual, embora busque manter uma aparência heterossexual. Tinha medo de que outras pessoas de seu círculo de relaçôes descobrissem sua homossexualidade e pensava: 'Eu sou gay, só que nunca vou falar isso para ninguém e nunca vou ter nenhuma atitude gay'. Assim, tem namoradas e busca prostitutas com quem apenas conversa. Ao frequentar o Projeto Purpurina, faz amizades e aumenta sua autoaceitação como gay. Assume-se para a família, amigos e faculdade. Pedro enfrenta dificuldades com a família, como a negação de sua mãe em relação a sua homossexualidade, e com seus amigos heterossexuais. Tem receio do que pode enfrentar no mercado de trabalho se sua homossexualidade for exposta, mas ainda assim refere que mantém uma perspectiva positiva de futuro.

Para mapa corporal (Figura 1), Pedro escolhe uma postura deitada lateralmente para demonstrar uma de suas características mais fortes: a timidez. Realiza o contorno do corpo em azul, sua cor preferida. Produz um símbolo para falar de si: no centro há um furacão de duas cores diferentes, azul e rosa, para demonstrar confusão, oposição e indecisão no processo de se assumir homossexual e em relaçáo a si próprio. Essas cores também simbolizam suas dúvidas se passaria a gostar de "coisas de menina". Coloca uma aliança no centro do furacão, para representar o conflito nas relaçóes sociais, e sua preocupação com a opinião das amizades e dos familiares. Refere que antes de tomar alguma atitude pondera no que as pessoas poderão dizer e pensar, mas que acaba por fazer o que é melhor para si. Para finalizar seu símbolo, adiciona um par de asas com dezesseis círculos, simbolizando a idade em que "se libertou", indicando um processo difícil, mas gratificante. Escreve o lema - "Se for mudar algo náo tente mudar como você é, apenas mude o ângulo de como você se enxerga".

Para falar de mudanças, faz um globo giratório no pescoço, um lugar vital, indicando mudança de posição. No braço, desenha uma rua e uma folha de espinafre para representar a força para seguir o próprio caminho. Simboliza a tranquilidade 


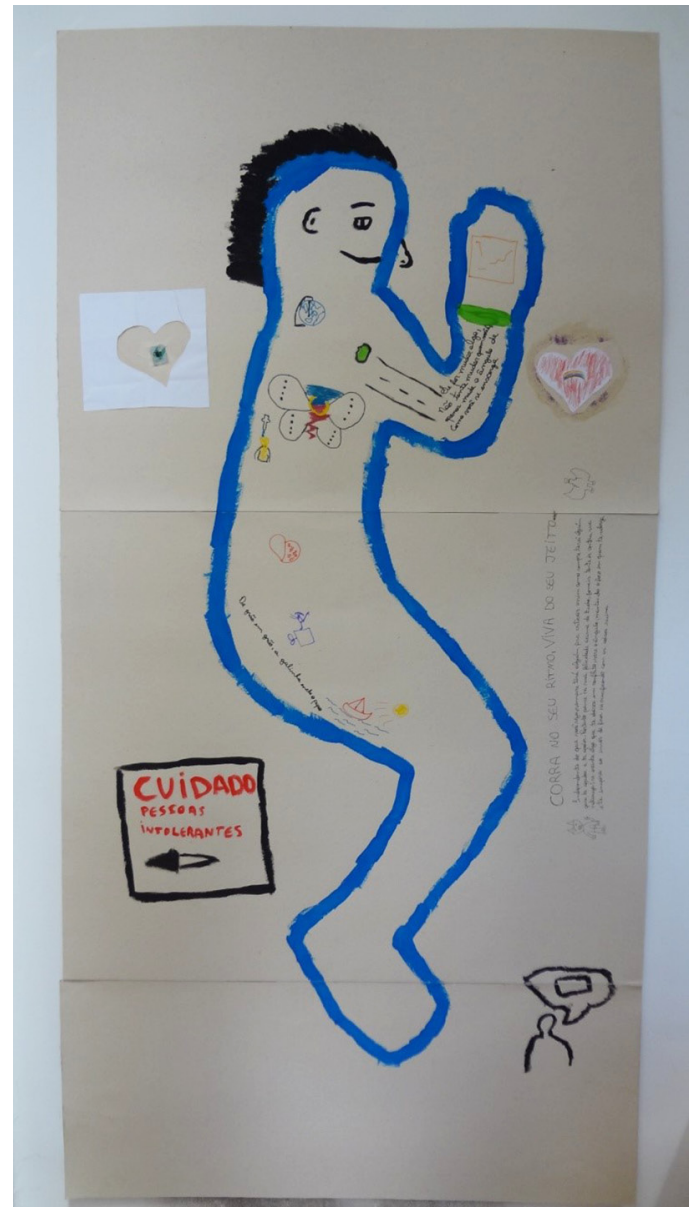

Figura 1. A história e o painel de Pedro.

sentida após se assumir com uma pulseira verde no punho e um barco. Apresenta o conflito entre razáo e emoçáo com um símbolo metade cérebro e metade coração. Nas costas, um coração vazio com um chip dentro, para representar o sentimento de ir mais de acordo com os desejos dos outros do que os seus, como um "robô".

Pedro escreve um ditado popular - "De gráo em grão a galinha enche o papo" - e desenha dois símbolos, um conta-gotas e uma caixinha de música. Esta por considerar que é necessário que as pessoas "deem corda" para sentir-se à vontade. O ditado e o conta-gotas são para representar seu modo de assumir-se para as pessoas paulatinamente, tentando descobrir o que as pessoas pensam sobre o assunto. Em relação ao assumir-se, também faz uma pessoa com um baláo de fala com uma lousa para representar aquilo que o ajuda, falando de inspiração em histórias positivas.

As dificuldades que aparecem em seu painel abordam o preconceito. Pedro desenha um tijolo em sua mão para falar sobre seu medo do afastamento das pessoas ao assumir-se, como se ele construísse "um muro que o separa das pessoas", e produz uma placa com os dizeres “Cuidado, pessoas intolerantes", em vermelho, em cima de uma adaga, para representar o preconceito existente na sociedade. A mensagem final é de incentivo:

Independente do que você seja, sempre terá alguém para criticar, assim como terá alguém para te ajudar e te apoiar. Portanto, pense na sua felicidade acima de tudo, jamais tente ir contra a sua natureza. Se existe algo que te deixa em conflito, vire o ângulo, mantendo o foco em quem te valoriza e te inspira ao invés de ficar se crucificando com as coisas ruins.

\subsubsection{Lucas}

Lucas é um jovem gay de 20 anos, que se considera extrovertido e 'brincalhão', e que gosta de fazer as pessoas se sentirem à vontade. Atualmente não trabalha nem estuda, pois trancou a matrícula na faculdade. Ultimamente seu cotidiano consiste em ajudar sua irmá a cuidar das sobrinhas gêmeas ainda bebês.

Lucas relata que, em suas lembranças da infância, tem memórias fortuitas sobre sua atração por homens, dizendo que sempre soube que era gay. Quando tinha aproximadamente 8 anos de idade, conta que sofreu uma experiência traumática, da qual não recorda detalhes, mas sabe que algo aconteceu com um menino mais velho e que apanhou de seus pais por isso. Como foi uma experiência ruim, não pensou mais sobre o assunto e tentou seguir sua vida de acordo com a educaçáo moral que recebia. Com o tempo, foi sentindo-se confuso e sufocado. Tentou ocupar seu tempo com estudo, música e desenho para náo pensar sobre sua sexualidade. Seu dia a dia estava programado entre escola, família e igreja. $\mathrm{Na}$ escola era tratado como "o bichinha", e o pai estranhava seu comportamento para um garoto.

Tenta se matar. Sobrevive e relata que essa tentativa o faz querer experimentar seus desejos sexuais. Aos 16 anos tem sua primeira relação sexual e considera-a positiva. Começa a construir amizades e conhece o Projeto Purpurina, que o ajuda a enfrentar o processo de se assumir homossexual. Relata não ter mais problemas para se assumir nos diferentes locais que frequenta, mas teme se isso poderá ser visto como "desonroso" no trabalho. A mãe ainda está no processo de aceitação e suas relações com outras pessoas estão melhores. Lucas relata força para lutar contra o preconceito e a discriminação e deixa mensagens positivas e de incentivo em seu painel. 
Para realizar seu painel (Figura 2), escolhe uma postura que mostra sua espontaneidade e traça o contorno do corpo em verde, sua cor favorita. Para se representar, desenha o Ohm no peito, pois considera que atualmente está em harmonia consigo. Seu lema "Você é a melhor parte de mim", escrito transversalmente ao corpo, para representar a totalidade de si, fala do sentimento de sentir-se bem consigo mesmo.

Pinta seu corpo com as cores do arco-íris, para falar do processo de se assumir. Refere querer pintar algo alegre e colorido, pois considera que anteriormente seu mundo era "sem vida", "sem graça", "sem cor". Desenha algemas partidas, para mostrar um sentimento de liberdade ao sair do armário, escrevendo: “Liberte-se". Na parte superior, desenha um balâo de fala em tons fortes, para representar que "colocou a boca no trombone", o que mostra seu lado mais sociável e a defesa de suas ideias, associando a frase: "Exponha suas ideias". As palavras 'família' e 'amigos' são dispostas ao lado do corpo, pois indicam relacionamentos importantes.

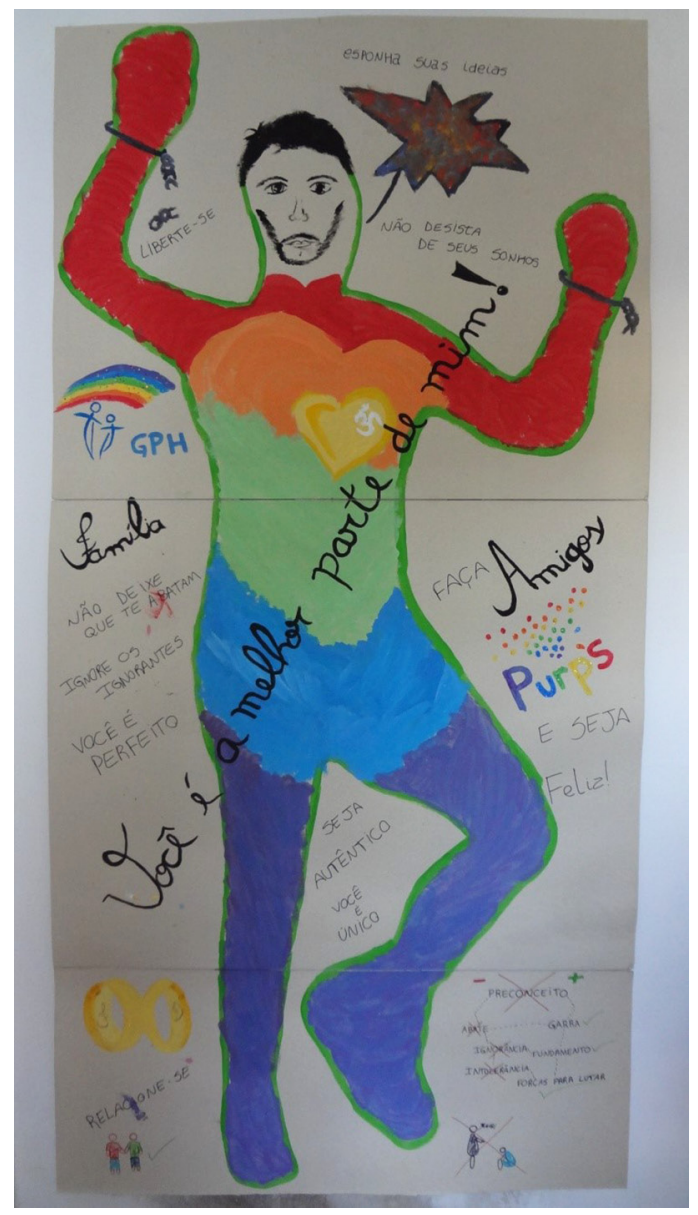

Figura 2. A história e o painel de Lucas.
Faz referências ao Projeto Purpurina, que ofereceu suporte a si e a sua família, escrevendo Grupo de Pais de Homossexuais (GPH) perto da palavra 'família', e 'Purp's' ao lado de 'amigos'. Escreve a palavra 'faça', acima de 'amigos', e 'e seja feliz' abaixo de 'Purp's'. Escreve as frases "Náo deixe que te abatam", "Ignore os ignorantes" e "Você é perfeito".

Próximo aos pés, faz um fluxograma do preconceito, contrapondo o que considera positivo e negativo. Realizando um jogo de oposiçáo entre as palavras, assinala como negativo que o preconceito 'abate', gera 'ignorância'e 'intolerância', e como positivo que ele dá 'garra' para lutar, gera 'fundamento' contra a ignorância e que dá 'forças para lutar' contra a intolerância. Abaixo do fluxograma, desenha dois bonecos para representar a discriminação. Ao final, faz um "X" vermelho naquilo que considera negativo e um visto verde no que é positivo. Desenha duas alianças para representar o seu relacionamento amoroso atual, e escreve: "Relacione-se". Escreve mais três frases no painel: "não desista de seus sonhos", "seja autêntico" e "você é único". Segundo Lucas, seu processo de assumir-se e revelar-se náo se deu de maneira fácil, confrontou muitas barreiras e mostra que atualmente o importante é poder ajudar outros a enfrentarem o processo de se assumir.

\subsubsection{Maria}

Maria é uma jovem lésbica, estudante universitária de 23 anos. Realiza estágio em uma empresa, em trabalho similar a operadora de telemarketing. Considera-se introspectiva, mas gosta de conversar.

Maria não se percebia enquanto lésbica e foi descobrindo sua homossexualidade ao longo de sua trajetória. Olhando o passado, relata haver indícios de sua homossexualidade, mas que os percebe apenas retrospectivamente. Refere como momentos indicativos para si, quando sente atração por amigas, embora relacione o interesse em beijá-las, abraçá-las e ter contato físico, às boas amizades que possuía. Seu primeiro contato com a homossexualidade é por meio de amigos com quem se corresponde por cartas, e com o tempo passa a gostar de uma dessas amigas e a namorá-la. Acha inicialmente que é bissexual, o que náo considera ruim, pois gosta de se considerar diferente dos outros. Diz que sua criação sempre foi voltada para respeitar as diferenças, e achando que sua mãe não teria problemas, assume-se para ela através de uma carta. Sua máe não reage bem e isso a marca como seu primeiro impacto negativo.

Maria vai definir-se enquanto lésbica um pouco mais velha, em um momento em que tem a 
oportunidade de "ficar com um menino", mas não consegue. Atualmente sua preocupação em assumir-se se refere ao trabalho, apesar de já ser assumida em seu emprego atual. Preocupa-se com o que poderá acontecer no futuro quando mudar de emprego e se isso influenciará sua ascensão profissional. Relata que sua relação com a mãe está muito boa e aponta o GPH e o Projeto Purpurina como importantes nesse processo. Sua mensagem final mostra a importância de ter suporte pessoal e familiar para os processos de assumir a homossexualidade.

Maria se desenha de lado para representar seu lado introspectivo, com contorno em roxo, sua cor favorita (Figura 3). O símbolo que escolhe para se representar é um coração, por retratar sua delicadeza, seu romantismo e seu lado mais sentimental e "carente". Como lema escreve duas frases: "Não há dor que o tempo náo cure" e "É errando que se aprende". A primeira se refere ao processo de se assumir, às dificuldades enfrentadas e ao vivido em relacionamentos amorosos anteriores. A segunda remete a seu aprendizado ao longo da vida.

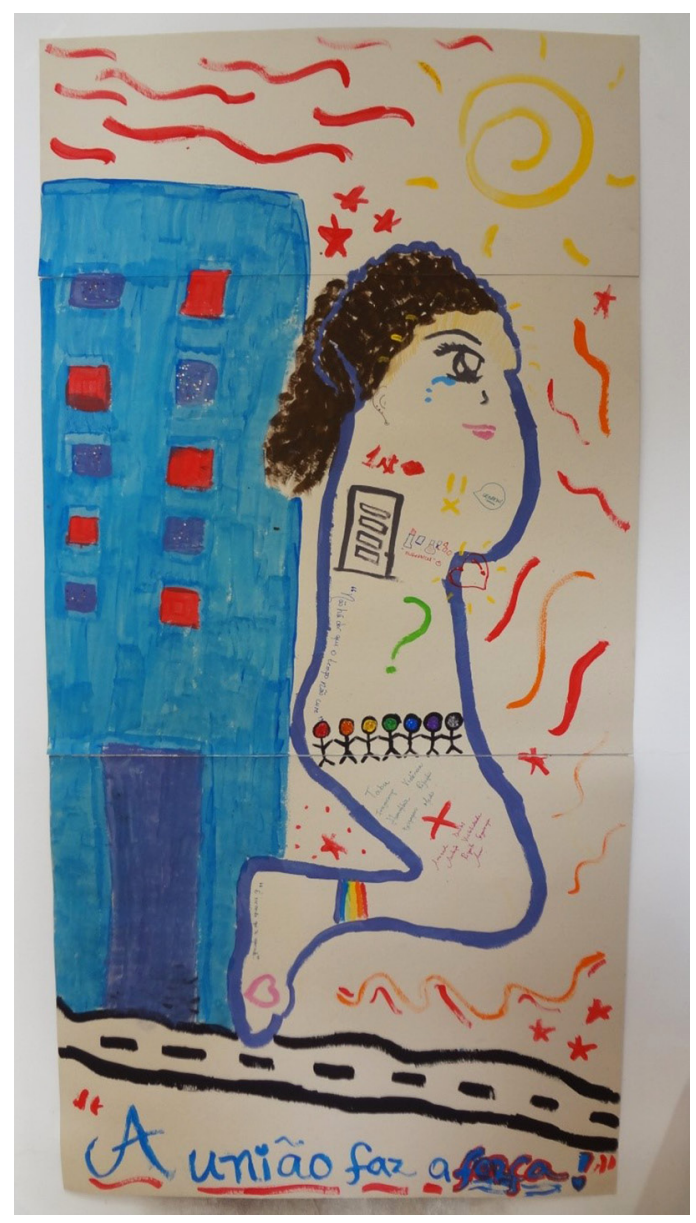

Figura 3. A história e o painel de Maria.
Representa sua força na cabeça, por seu lado mais racional, e no coração, que remete à afetividade e às pessoas que a cercam e dão suporte para enfrentar as vicissitudes da vida. Retrata seu lado mais sensível através de uma lágrima. Faz uma boca em ' $X$ ', para representar o tempo em que mantinha sua sexualidade em segredo por pressáo de sua mãe. Em referência ao se assumir, desenha a porta de um armário. Na regiáo abdominal, desenha um ponto de interrogação verde para simbolizar o processo de se entender como lésbica, suas dúvidas se seria bissexual e se continuaria a ser uma mulher feminina, retratando esse universo por um batom, um esmalte e a palavra 'mulherzice'. Relaciona esse conflito ao desejo de ser reconhecida enquanto lésbica por quem fosse da "comunidade" e para encontrar um relacionamento amoroso. Nesse processo, utiliza a estratégia de usar em sua vestimenta um símbolo LGBT, como uma pulseira com as cores da bandeira do movimento, representada no painel por uma tornozeleira.

Representa o que facilita ou dificulta o processo de se assumir com um jogo de palavras em oposição: "tabu", "insegurança", "violência", "homofobia", "rejeiçäo", "despreparo" e "medo" versus "amizade", “direitos”, "aceitação", "visibilidade”, "respeito”, “segurança” e "amor". Desenha os ambientes que frequenta pelas figuras de uma rua e um prédio, cuja entrada em cor roxa representa o tempo em que vivia em seu "mundo lilás". As janelas em duas cores: roxo para os lugares bons, em que se sente mais à vontade, e vermelho para os lugares ruins. Com a fileira de bonequinhos quer representar suas amizades e a importância que têm em sua vida. Sua mensagem final - "A uniáo faz a força" - retrata sua perspectiva de que é necessário que os gays e lésbicas se unam para lutar por seus direitos.

\subsubsection{Joana}

Joana é uma jovem lésbica de 22 anos, estudante universitária. No momento realiza estágios de curta duração pela faculdade em vários locais. Relata que o processo de se perceber lésbica se deu de forma 'natural', sem muitos 'problemas'. Tinha namorados antes de ter uma experiência homossexual e apenas considerava estranho o fato de não gostar de beijar e se relacionar com seus namorados, mas náo pensava que isso indicasse uma possível homossexualidade. Somente depois de se relacionar com meninas é que passa a pensar em sua sexualidade e a questioná-la. Relata não ter tido muitos problemas de autoaceitação, relacionando o fato a sua criação de respeito às diferenças. No entanto, a resposta de sua mãe ao 
se assumir torna seu relacionamento conflituoso. Embora atualmente sua mãe aceite melhor sua homossexualidade, ainda sente que não pode dizer certas coisas e sofre com o que é velado. Assumir-se no trabalho é uma preocupação, dependendo de onde estiver trabalhando. Apesar das dificuldades enfrentadas, tem uma perspectiva positiva do futuro.

Joana opta por se desenhar na posição que gosta de ficar - sentada, pois é confortável e condiz com a sua personalidade calma (Figura 4). Sua cor favorita é o roxo, mas, como náo havia a cor no momento, resolveu realizar o seu contorno em rosa. Escolhe como símbolo para se representar um "smile" no peito, significando estar bem consigo e que um "coração feliz" traz "ideias boas". Como lema utilizou-se da frase "Posso náo concordar com uma palavra do que você diz, mas me deixaria bater até a morte pelo seu direito de poder dizê-la" e colocou-a contornando seu corpo com a simbologia de que a liberdade de expressão não se restringe a apenas uma parte do corpo e sim a todo ele.

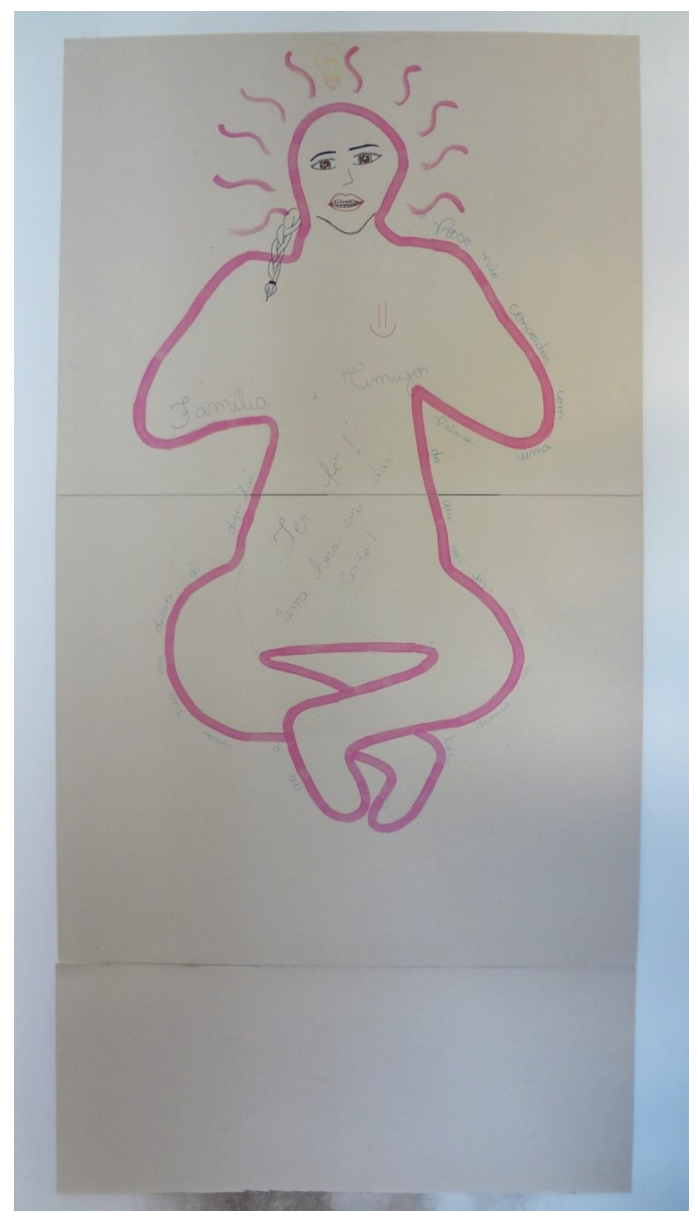

Figura 4. A história e o painel de Joana.
Acha a liberdade importante em sua vida e relata tentar praticá-la no dia a dia. Representa sua força por meio de uma lâmpada acima da cabeça, pois considera que ela vem de suas ideias, de sua racionalidade. Dando um pouco mais de ênfase, desenha traços saindo da cabeça, pois náo para de pensar. Não desenhou muito símbolos em seu painel, preferindo falar. Escreve "família e amigos" no tronco de seu corpo, porque considera essas relaçôes muitos importantes em sua vida. Como mensagem final, usa palavras de incentivo: "ter fé!"' e "uma hora vai dar certo!".

\subsection{Percepções e representações do se assumir homossexual}

Durante a realização do painel, as questōes disparadoras foram proporcionando aos participantes oportunidades para manifestarem suas percepçóes sobre o processo de se assumirem homossexuais e, ao mesmo tempo, as representaçôes que permeiam seus discursos e remetem a ideias que são produzidas social e culturalmente. A análise de conteúdo revelou categorias temáticas centrais, sintetizadas na Figura 5 e organizadas em três eixos principais -2 horizontais e 1 vertical.

O primeiro eixo horizontal - Preconceito, Estigma $e$ Empoderamento - se refere às representaçóes que os participantes manifestam ao discutirem sobre como a homossexualidade é entendida e referida socialmente e como os processos de resistência e empoderamento operam em resposta a situaçóes que são facilitadoras ou geram barreiras sociais. Os facilitadores foram entendidos como suporte para o processo de se assumir homossexual e as barreiras sociais como situaçôes resultantes da propagação de preconceitos e estereótipos negativos sobre os homossexuais.

O segundo eixo horizontal - Discriminação, Isolamento e Participação Social - se refere às percepçóes dos participantes de como o processo de assumirem afeta seu cotidiano. Discorrem sobre os processos de discriminação e isolamento que viveram (ou vivem) e suas estratégias para exercerem sua participação social, principalmente nos espaços familiar, escolar, do trabalho e de convivência social e cultural. Essas estratégias estão relacionadas à forma como revelam ou encobrem a homossexualidade, com o intuito de se protegerem de possíveis consequências.

Como uma categoria complementar, mas presente em suas histórias de vida e narrativas, o eixo vertical - Possibilidades de Transformação e Projetualidade - sintetiza como os participantes 


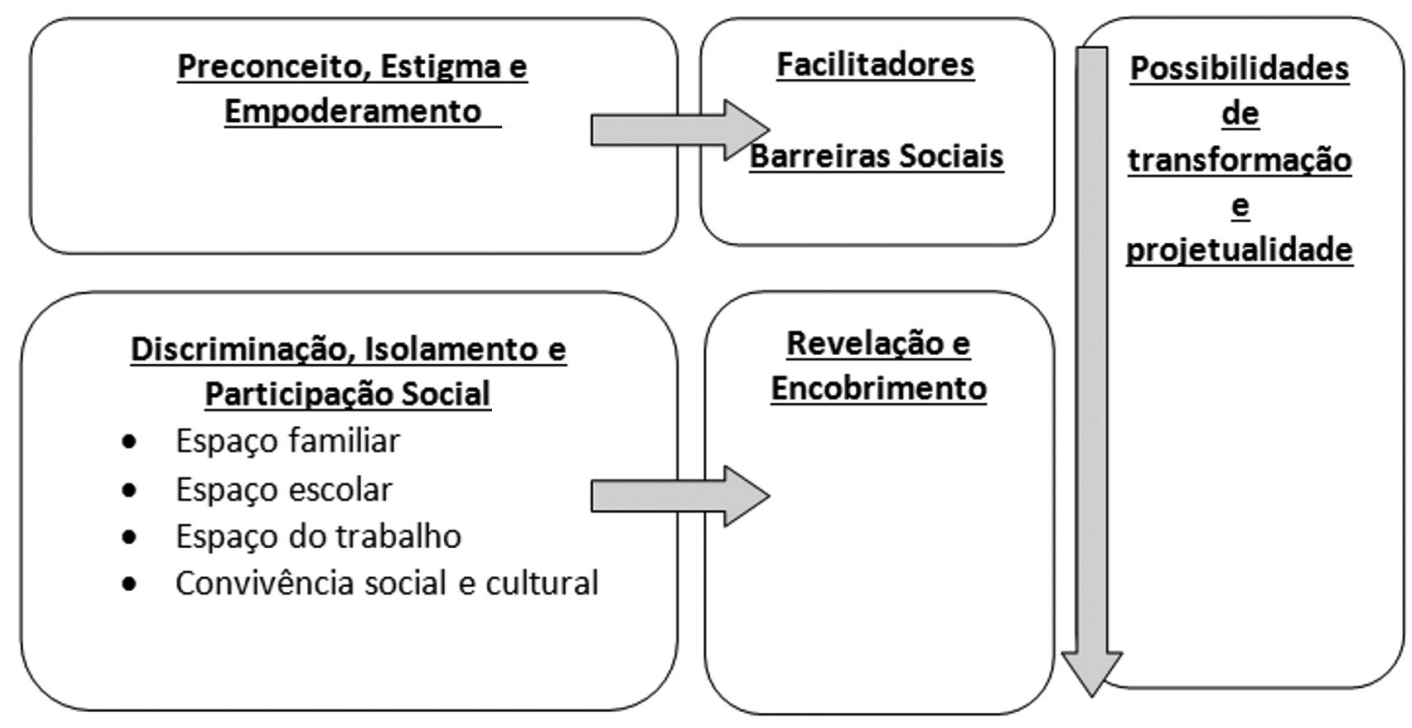

Figura 5. Categorias centrais temáticas que abordam representações sociais, percepções dos participantes e suas expectativas de futuro.

vislumbram as expectativas para si, em termos de seus projetos de futuro, e para a transformação da sociedade, em termos do respeito à diversidade sexual.

\subsubsection{Preconceito, estigma e empoderamento}

Preconceito e estigma são questôes presentes nas narrativas dos participantes, revelando a preocupação tanto de sua influência no modo como são vistos e julgados com o da associação de suas açôes à sua sexualidade.

O gay é malvisto, quanto mais coisas erradas ele fizer, mesmo que náo tenha nada a ver com isso, todo mundo vai chegar [e dizer] porque ele é gay ele é daquele jeito, além de ser gay ela é isso, isso $e$ isso (Maria).

Como aponta Seffner (2011, p. 43), gays e lésbicas "[...] são vistos em geral como identidades a corrigir, indivíduos a serem curados pela medicina ou pela intervençáo da religião", o que corrobora o sentimento de preconceito expresso por Maria.

Segundo Nunan (2003), a homossexualidade frequentemente é atrelada às ideias de promiscuidade, pedofilia e imoralidade. A produçáo desses estereótipos aparece nas falas dos participantes a partir de suas vivências.

Se é um professor gay, já vai achar que o cara é pedófilo (Maria).

Tem todas aquelas ideias de [que] o gayépromiscuo, ele é, sei lá, escolheu ser assim, e mais uma coisa do demônio, sabe? Essas coisas absurdas. E aí todo mundo já te vê como algo negativo. Pensar que você pode não ser aquilo que vocêé (Maria).

[...] a pessoa fala "Ai que legal ter um amigo assim", mas só que ela pensa que aquele amigo é assim porque é uma pessoa promiscua, sabe? [...] Que falam como se fosse lindo (Lucas).

Foi também frequente a preocupação com os comportamentos de gênero. Os participantes referem a confusão social que se faz entre gênero e sexualidade. Comportamentos considerados de determinado gênero são confundidos com a orientação sexual da pessoa. Assim, referem experiências no sentido de que, se a pessoa é homossexual, consequentemente terá um comportamento de gênero relativo ao seu oposto.

Eu acho que eles [amigos héteros] vão me olhar mais menina, não vão mais comentar de nada, por exemplo, esporte já evitam comentar. Acham que eu vou mudar todos os meus gostos (Pedro).

Ao longo do processo de assumir-se homossexual, os participantes relatavam também uma forma de apropriação de seu processo de se assumir, superando seus próprios preconceitos.

Eu cheguei a comprar uma [pulseira com as cores LGBT] na parada [gay], foi a primeira que eu fui. Usei ela por um bom tempo ..., ai depois eu comprei outra que eu também usava assim direto. Depois parou. Também chega numa altura que vocêfala: "Ah, não preciso de mais nada disso. Eu estou bem comigo mesma, eu sou assumida, então não tenho que ficar andando com a pulseirinha..."(Maria). 
Um aspecto facilitador importante no processo de sair do armário, apontado por todos os participantes, foram as respostas positivas ao se revelar para outras pessoas ou a presença de uma rede social que desse suporte, destacando-se os amigos e familiares.

[...] o que facilita é isso mesmo. Ter gente que te aceita indiferente de vocêser muito chato, de você ter seus dias de TPM, que fala: "Meu, fica quieta ai no canto, porque tá dificil" (Joana).

$A h$, ter pessoas que me aceitam, e me respeitam e me apoiam. Essas três coisas. Tem gente que nem sempre aceita. Ela respeita o que você é, mas não necessariamente aceita. Mas é importante ter pessoas que: "Ah, tô de boa, não muda para mim o que você é". Você vê que é seu amigo acima de tudo, que é sua família acima de tudo. [...] Eu contei para os amigos e foi tranquilo. Então eu senti que podia contar para a família. Quando com a família ficou tudo de boa, ah, então eu já posso me abrir para o mundo porque eu sei que se alguma coisa der errado, en vou ter aquelas pessoas a quem recorrer (Maria).

Deve-se considerar que a maioria das experiências dos participantes em se assumir resultaram positivas. Mesmo aqueles que tiveram conflitos familiares, atualmente consideram que suas situaçóes estejam melhores do que anteriormente, quando não eram assumidos. Além disso, todos os participantes obtiveram o apoio necessário de alguma rede social próxima para enfrentar seu processo. A existência de um projeto que ofereça suporte, como o Projeto Purpurina, mostra-se como um importante elemento facilitador.

O Projeto Purpurina ajudou bastante, inclusive até eu conhecer melhor o que que eu era, o que é ser gay e inclusive outras coisas (Pedro).

Foi também identificado como aspecto facilitador, conhecer pessoas homossexuais pessoalmente ou pela mídia.

Ah, sim, facilitou eu me aceitar melhor... ver pessoas que eu admiro que são também... que eu não imaginava. Que nem eu descobri que um professor meu era... dá para ser gay e ser uma pessoa boa, ser uma pessoa bem-sucedida (Pedro).

Ela [Ellen Degeneres] eu acho que é uma pessoa que ajuda. Porque, quer queira quer não, ela tem um pouco do estereótipo que todo mundo espera, $e$ ainda assim ela conseguiu o espaço dela, é respeitada daquele jeito que ela é (Joana).

Ao mesmo tempo, todos os participantes apontaram o preconceito ou a discriminaçáo como produtores de barreiras sociais e falaram sobre o medo de sofrer algum tipo de agressão.
Sempre que você vai brincar de alguma coisa, por exemplo, quando você briga com um amigo, [escuta]: "Vai, seu gay". [...] é uma maneira ofensiva de falar, isso náo pode ser uma coisa boa (Pedro).

Em pesquisa de Venturi e Bokany (2011), 99\% dos entrevistados manifestaram preconceito contra as pessoas LGBT, incluindo-se os preconceitos velados de que fala Pedro. A pesquisa também revela que $53 \%$ dos gays e lésbicas entrevistados já tinham se sentido discriminados em algum momento de suas vidas. Estes dados corroboram a vivência de Pedro, Lucas, Maria e Joana, que ao viverem preconceitos em suas histórias de vidas, passam a se preocupar ou temer a discriminação, o que resulta em acuamento da revelação de sua orientação sexual.

Todos os participantes também apontaram a religião como uma barreira importante, não apenas no âmbito pessoal, por causa dos conflitos com seus valores, mas principalmente no âmbito macrossocial devido à propagação de preconceitos.

Ela [Igreja] faz diferença porque usam a Igreja para bater de frente. Ela não é indiferente, usam ela para atacar. Isso que incomoda. É uma coisa bem contraditória, eles falam que a Igreja é um lugar para acolher, mas na verdade eles excluem muita gente e ainda atacam aqueles que eles excluem (Pedro).

A família nuclear ou expandida foi referida como um fator complicador. Duas participantes também relataram haver uma preocupação em 'se assumir' pelas consequências que poderia ter para seus pais e não para si.

Então eu tenho medo de chegar e fazer algum comentário e minha mãe "Ai, meu Deus, filha, o que você anda fazendo nessa faculdade", então eu tenho mais receio por conta dos meus pais, mas não por conta das pessoas em si (Joana).

Como aponta Castañeda (2007), quando alguém se assume homossexual leva consigo a sua família, que sofre um processo similar ao seu:

Assim como o homossexual teve de lutar longamente com a dúvida, a vergonha e o medo antes de se abrir com seus pais, estes deverão decidir, por sua vez, o que farão em relaçáo ao restante da família, dos amigos, dos vizinhos e da sociedade em geral (CASTAÑEDA, 2007, p. 116).

Três participantes apontaram como barreira a produção midiática do preconceito veiculado pelas novelas, reportando-se a personagens de novelas brasileiras para exemplificar suas histórias. 
Antes eu só conhecia o lado ruim de [ser] gay. O lado justamente que a mídia passa muitas vezes. Estereotipado (Pedro).

E isso [o personagem da novela] atrapalha bastante porque as pessoas começam a relacionar: "Ah, $o$ homossexual é assim", "Ah, eu acho tão lindo, só porque ele faz aquelas brincadeiras". Mas acaba sendo o palhaço, submisso, sendo aquela pessoa que é apontada, é chacota. Eé supernegativo isso também (Lucas).

Nessa mesma direção, dois participantes também manifestaram que posicionamentos de pessoas públicas contrárias à homossexualidade aumentam as barreiras sociais, principalmente se vindo de alguém que interpreta um personagem homossexual.

\subsubsection{Discriminação, isolamento e participação social}

Ao discorrem sobre os processos de discriminação e isolamento, os participantes oferecem vários exemplos de como esses processos acontecem nos espaços familiar, escolar, do trabalho e de convivência social e cultural.

No espaço familiar foi possível constatar tensóes existentes principalmente relacionadas à figura materna. Uma das participantes citou o pai como não participando muito de sua vida, e um dos participantes náo falou sobre seu pai, o que pode influenciar a maior presença da máe enquanto uma relação importante dentro de casa. Um participante relatou que sua mãe ainda ignora sua homossexualidade, dois citaram como um relacionamento difícil e uma com um bom relacionamento atualmente, mas ruim quando descobriu. O espaço familiar nem sempre é visto como um lugar tranquilo para se estar:

Eu não posso estar vendo ou lendo alguma coisa no computador, conversando direito no MSN, com medo de alguém chegar e ver, e às vezes ver uma coisa e distorcer de outra forma e acabar usando isso contra mim ou pensando algo que eu não sou (Pedro).

É possível observar também manifestaçôes preconceituosas por parte da família - explícitas, veladas ou na forma de chacotas e brincadeiras:

Outro dia estava passando a Parada Gay, ele [pai] disse: "Vou matar todo mundo, vontade de tacar bomba nesse lugar" (Pedro).

Meu irmão fala: "Ah, vamos ao futebol comigo?". E eu: "Eu não gosto!"... Ele: "Você gosta de vôlei, né?". Ai eu falo: "Não, não gosto de vôlei também, e se eu gostasse, qual o problema?" [...] Eu já falei que eu gosto de luta. Ele já começa: "É lógico, fica se agarrando com homem" (Pedro).

Eu respeito, ela [mãe] respeita, mas ainda tem aquela coisa que é velada assim, que, é muito ruim, mas melhorou muito, não reclamo, está melhor (Joana).

Em relação ao espaço escolar, os resultados da pesquisa indicam uma diferença de aceitação entre os espaços da escola e os da universidade. Os participantes relataram maiores problemas no colégio, tendo apelidos e sofrendo chacotas.

Em relação à universidade, os participantes relataram que neste espaço se sentem mais confortáveis para se assumir. Estes resultados corroboram a pesquisa de Venturi e Bokany (2011), que mostra que os índices de pessoas que têm contato com gays e lésbicas varia conforme o nível de escolaridade da pessoa. Aqueles com nível superior apresentaram mais contato com gays e lésbicas do que os que apenas frequentaram a escola (VENTURI; BOKANY, 2011). Carrara e Lacerda (2011) tecem consideraçóes a respeito dos resultados, dizendo que, no nível superior, gays e lésbicas sentem-se mais confortáveis e seguros para assumir sua orientação sexual.

O espaço do trabalho foi alvo de preocupação. Todos os participantes relataram algum receio de que sua homossexualidade afetasse sua profissão.

Eu me preосиро em me assumir no trabalho, porque tenho medo disso influenciar, sei lá, eles não quiserem contratar, melhorar alguma coisa, não confiar tanto em mim. Achar que minha sexualidade interfira no meu jeito de ser, no meu jeito de trabalhar. Eu tenho um pouco de medo, sem contar que vai ser num ambiente novo ainda. Eu me preocupo bastante em como eu vou me relacionar com as pessoas, sabe? Porque trabalho você tem que ter uma relaçáo boa com o ambiente, para conseguir se desenvolver também (Pedro).

É, muita gente acha que ser gay é uma coisa... bagunçada, sabe? Uma pessoa desonrosa para o trabalho (Lucas).

Eu sei que eu teria uma preocupação de, dependendo de onde eu trabalho, não sei se eu falaria. Demoraria um pouco (Joana).

Quando eu mudei [de trabalho] fiquei com medo de ter que ficar no armário. Eles me apresentaram, [...] a empresa, os valores e tudo, falaram que eram contra qualquer tipo de discriminaçâo. Mas é que na teoria é assim e na prática não é. Felizmente realmente lá na prática é tudo bem tranquilo. 
Mas eu tenho medo de mudar para outro lugar e ter que ficar [no armário] (Maria).

Em relação aos espaços de convivência social e cultural, os participantes relataram uma diferença entre os locais ditos de sociabilidade LGBT e os demais lugares de convivência social. Essa questáo apareceu mais intensamente entre os rapazes, que realizavam uma diferença entre os locais "gays" e os locais "héteros". Os participantes referem sentir-se melhor em espaços LGBTs, principalmente se houver alguma forma de interação de cunho afetivo ou sexual (como "paqueras"):

Toda vez que me chamam eu vou [para a balada]. Já com hétero não, eu sempre tento inventar uma desculpinha (Pedro).

O medo da violência em espaços públicos foi relatado por todos os participantes:

Eu tenho um pouquinho de medo de violência [...]. Pode ser qualquer dia, um dia inesperado acontecer algum tipo de preconceito e partir violência [...]. Qualquer lugar público é possivel (Lucas).

Tenho medo assim quando eu saio com o pessoal, ainda mais que a gente está vendo muitos casos de violência na regiäo da Paulista [...] toda a vez que a gente se dispersa eu falo: "Gente me avisa quando vocês chegarem em casa, me manda mensagem que eu fico com o coração na mão" (Maria).

Importante destacar que as entrevistas aconteceram na época em que a mídia relatava frequentes agressóes realizadas contra homossexuais, o que pode ter influenciado as respostas dos participantes. Entretanto, Venturi e Bokany (2011) apresentam dados de que $52 \%$ dos gays e lésbicas já sofreram alguma forma de violência, sendo $7 \%$ violência física ou lesão corporal.

As estratégias de revelação ou encobrimento são formas de resposta às situaçôes de discriminaçáo. Elas podem gerar mais isolamento ou abrir oportunidades de participação social. A dissimulação foi apontada como estratégia:

E eu só tentando disfarçar. Eu saía às vezes para a balada hétero só para pegar um monte e ficar falando que eu sou hétero (Pedro).

Segundo Seffner (2011), as estratégias de anonimato podem proteger os indivíduos de agressóes, podendo ser um dos motivos para uma necessidade de encobrimento e dissimulação.

Uma estratégia para se assumir apresentada pelos participantes é a de tentar deixar explícito de alguma forma a sua homossexualidade, por exemplo, utilizando-se dos estereótipos e símbolos homossexuais:

Já que eu não podia me assumir, chegar e falar eu sou, queria que as pessoas olhassem para mim e já soubessem só pelo visual e não por ter feito piadinha (Maria).

Três participantes relatam sua opçáo por ir se revelando aos poucos:

Eu tento ser meio indireto para saber o que a pessoa pensa a respeito de ser gay, por exemplo, eu falo. "Ah, fui em tal balada, ai uma vez me arrastaram para uma balada gay" (Pedro).

A estratégia utilizada busca conhecer as percepçóes que as pessoas têm sobre a homossexualidade, criar um vínculo, para depois se assumir.

\subsubsection{Possibilidades de transformação e projetualidade}

As narrativas dos participantes também apontam como lidam com suas expectativas de futuro em resposta a como suas vidas foram se transformando ao longo do processo de se assumirem homossexuais. Suas trajetórias sáo parecidas em relação ao sentimento que provocam. Todos os participantes relataram sentir-se melhor depois de se assumir, sentiram-se mais livres.

Eu pintaria uma coisa colorida, porque o mundo para mim antes era [...] sem cor, sabe? Sem graça, sem vida, porque eu era muito fechado e depois o arco-íris brilhou para mim, então é uma coisa colorida (Lucas).

Agora eu posso fazer esse comentário, antes eu olhava 'ah, bonita' e ficaria na minha. Então eu tenho mais abertura de falar o que eu penso (Joana).

Dar continuidade à vida, ter perseverança e nunca desistir são ideias vistas como importantes ao se passar por processos difíceis. Como todos os participantes consideram se sentir melhor agora, suas mensagens são positivas.

[...] nunca desistir, não se abater com o que as pessoas falam. Porque se vocêse abater com o que as pessoas falam, apontam, se referem, a gente desiste. Não pode deixar [...] essa luz que brilha na gente apagar, porque não tem algo na vida que justifique isso [...] que valha a pena (Lucas).

Tudo que a gente passa pode ser uma coisa boa ou ruim, sempre vai ter uma lição. Por mais que você sofra assim horrorosamente sempre vai tirar alguma lição disso (Maria). 
Em síntese, nos resultados obtidos foi possível identificar situaçóes de preconceito e discriminação que os participantes tiveram, e ainda têm, que enfrentar. Para isso, é necessário retomar o conceito de homofobia como o preconceito e discriminação perpetrados contra homossexuais, bissexuais, travestis e transexuais (RIOS, 2009).

A homofobia compreendida a partir do heterossexismo (RIOS, 2009) fornece uma base mais ampliada para se compreender a temática estudada. Nessa perspectiva, ela atua como instrumento regulador de nossa sociedade (RIOS, 2009) e faz parte das instituições disciplinares existentes. Disciplinar no sentido de um exercício de poder em relação aos corpos para normalizá-los e atribuir-lhes identidades de forma arbitrária e naturalizada (PRADO; JUNQUEIRA, 2011).

Segundo Prado e Junqueira (2011), a família e a escola fazem parte dessas instituições e têm um papel crucial para o estabelecimento da norma heterossexual, como foi possível observar nos resultados da pesquisa. Chama-se atençáo para os momentos em que a família apareceu como uma barreira social, como um espaço onde há tensões, não sendo tranquilo de se habitar o espaço domiciliar, onde se convive com constantes manifestaçóes preconceituosas, que nada mais são do que formas de controle e de normalização que atuam sobre os sujeitos.

$\mathrm{Na}$ pesquisa da Fundação Perseu Abramo (VENTURI; BOKANY, 2011), realizada com gays e lésbicas, os familiares e os amigos da escola figuram entre os principais agentes discriminadores, corroborando com essa pesquisa. Seffner (2011) ainda complementa dizendo que são as pessoas próximas que têm o poder de afligir alguma forma de violência, sendo diferente ouvir um comentário delas do que de alguém desconhecido.

Nos resultados, a escola foi apontada como mais problemática para os meninos, com marcadores de apelidos que expunham suas sexualidades. Prado e Junqueira (2011) referem que as lésbicas estâo sujeitas a processos de invisibilidade, sendo mais identificadas apenas quando adotam comportamentos considerados mais masculinos. Talvez em razáo disso as meninas relatem menos problemas em relação à escola, sendo sua identificação por outros enquanto lésbica menos enfatizada.

Outra instituição disciplinar que aparece nos resultados da pesquisa é a religiáo, vista como uma barreira social importante no contexto macro e microssocial. Segundo pesquisa de Venturi e Bokany (2011), as ideias em relação à homossexualidade na sociedade brasileira estão atreladas a uma moral religiosa. Em sua pesquisa, $84 \%$ das pessoas entrevistadas concordaram totalmente com a afirmaçáa de que "Deus fez o homem e mulher com sexos diferentes para que cumpram seu papel e tenham filhos", e 58\% com a "a homossexualidade é um pecado contra as leis de Deus" (VENTURI; BOKANY, 2011, p. 200).

O trabalho em nossa sociedade possui uma grande centralidade na vida dos indivíduos. Ser discriminado no emprego, principalmente por posiçóes de maior poder, como chefias, é um fator complicador para o ingresso na vida profissional (SEFFNER, 2011). Todos os participantes relataram alguma ressalva em relação ao mundo do trabalho para assumir sua homossexualidade, refletiram se revelariam ou não e quais as possíveis consequências desse ato. Numa sociedade em que é frequente a discriminação contra gays e lésbicas por colegas de trabalho (VENTURI; BOKANY, 2011), é de se esperar que, adentrando nesse contexto, mostrem-se preocupados com seu futuro.

Os resultados da pesquisa retomam assim a importância da inclusão de questóes de gênero e diversidade sexual no âmbito da implementaçáo das políticas de proteção e promoçáo da diversidade, de modo que se possa prevenir que as diferenças culturais resultem na reprodução das

[...] desigualdades duradouras, baseadas em pares de categorias binárias de oposição [...] branco/negro; homem/mulher; cristãos/ judeus; nacional/estrangeiro; heterossexual/ homossexual etc. (GUIMARÃES, 2012, p. 41).

Ao mesmo tempo, essas políticas devem buscar proteger e promover a diversidade das expressóes culturais em suas constantes trocas e interaçóes de forma a garantir o patrimônio cultural dos povos e a interação entre as culturas.

Os resultados apontam também para a necessidade de uma maior apropriação do terapeuta ocupacional sobre o tema da diversidade e da cultura, que resulte em subsídios teórico-metodológicos ao exercício profissional em qualquer campo de saber e prática, e na produção de conhecimento em domínios pouco explorados, como o deste estudo. Tema que em sua amplitude abarca questôes, intolerâncias e conflitos no âmbito étnico, social, geracional, linguístico, religioso, político, sexual, de gênero, bem como os que resultam da produção de padróes de normalidade entre o sadio e o doente, o deficiente e o 'normal'.

\section{Conclusão}

A pesquisa constatou que os discursos vigentes em torno da homossexualidade permeiam as falas dos participantes principalmente nos assuntos ligados ao preconceito e discriminação à população LGBT 
no Brasil. É relevante destacar a importância da rede social próxima para o processo de sair do armário, manifestada pela solidariedade de amigos, pelo acolhimento e aceitação da família ou por projetos que favoreçam a criação de redes sociais de suporte.

Os resultados, entretanto, apontam processos de assumir-se homossexual mais reflexivos que são resultantes da sustentação proporcionada pelas trocas de experiências dentro de grupos de apoio e das vivências na universidade e em contextos da cidade de Sáo Paulo. Portanto, os resultados podem ser limitados para explicar os impactos de sair do armário para jovens em contextos de maior vulnerabilidade social, sem apoio de grupos de suporte ou vivendo em contextos sociais e culturais onde os debates acerca da diversidade cultural, em todas suas modalidades, são pouco frequentes ou aceitos.

Assim, enfatiza-se a importância de a agenda da diversidade sexual e de gênero adentrar os campos da Educação, da Saúde, da Assistência Social, da Cultura e do Trabalho, de forma a combater a naturalização da heterossexualidade como norma e, em contrapartida, a disseminação do preconceito, da homofobia e do silêncio vividos pelos jovens LGBT.

Um exercício de resistência exigiria ver-se de novos modos, dizer-se de novas maneiras, experimentar-se de novas formas, estranhar a imagem refletida no espelho que recorta nossas infinitas possibilidades, recusar toda miragem de identidade que nos torna limitados. Ensaiar formas curriculares que possam convidar à produção de novas formas de subjetividade, de novas estéticas da existência, desconstruir criativamente as fronteiras sexuais e de gênero (DINIZ, 2008, p. 490).

As estratégias de enfrentamento, entretanto, demandam um permanente exercício crítico de resistência, de forma que, ao se construir políticas de tolerância e de exercício pleno de direitos, como diz Diniz (2008), não se produzam novos assujeitamentos.

Afinal, não basta que as diferenças sexuais e étnico-culturais, como modos de pertencimento a coletivos, sejam crescentemente legitimadas no âmbito legal e político, nacional e internacionalmente. A luta pelo reconhecimento e respeito à diversidade acontece na trama cotidiana das relaçóes sociais com implicaçôes que podem resultar seja na transformação da cultura e das instituiçôes, seja na preservação das expressốes culturais tradicionais ou das minorias, de modo que, em ambas condiçôes, sujeitos, grupos, coletivos, comunidades e populaçóes possam conviver em clima de tolerância, justiça social e respeito mútuo.
O terapeuta ocupacional, à luz de seu compromisso ético e político, pode colaborar de forma significativa para favorecer a compreensáo e o enfrentamento das tensóes que continuam a ser produzidas e reproduzidas social e culturalmente, com vistas à ampliaçáo de modos de viver que se nutram pela partilha e pelo respeito, e não se definam por hierarquias étnicas, sociais, religiosas, linguísticas, políticas, sexuais e de gênero, dentre outras.

\section{Agradecimentos}

Agradecemos aos jovens que compartilharam suas histórias e disponibilizaram seu tempo para participar da pesquisa.

\section{Referências}

CARRARA, S.; LACERDA, P. Viver sob ameaça: preconceito, discriminação e violência homofóbica no Brasil. In: VENTURI, G.; BOKANY, V. Diversidade sexual e homofobia no Brasil. São Paulo: Editora Fundação Perseu Abramo, 2011. p. 73-87.

CASTAÑEDA, M. A experiência homossexual: explicações e conselhos para os homossexuais, suas famílias e seus terapeutas. São Paulo: A Girafa, 2007.

CASTEL, R. Da indigência à exclusão, a desfiliação - precariedade do trabalho e vulnerabilidade relacional. In: LACETTI, A. Saúde e loucura. Grupos e coletivos. São Paulo: Hucitec, 1994. p. 21-48.

DAVY, C. et al. Aspects of the resilience and settlement of refugee youth: a narrative study using body maps. Cadernos de Terapia Ocupacional da UFSCar, São Carlos, v. 22, n. 2, p. 1-11, 2014.

DEVINE, C. The moon, the stars and a scar: body mapping stories of women living with HIV/AIDS. Border Crossings, Canada, n. 105, p. 58-65, 2008. Disponível em: <http://bordercrossingsmag.com/magazine/issue/issue-105>. Acesso em: 6 abr. 2015.

DINIZ, N. F. Educação, relaçóes de gênero e diversidade sexual. Educação \& Sociedade, Campinas, v. 29, n. 103, p. 477-492, 2008.

FOUCAULT, M. História da sexualidade I: a vontade de saber. Rio de Janeiro: Graal, 1988.

FOUCAULT, M. Microfísica do poder. Rio de Janeiro: Graal, 1992.

FRY, P.; MACRAE, E. O que é homossexualidade. São Paulo: Brasiliense, 1991.

GASTALDO, D. et al. Body-map storytelling as research: methodological considerations for telling the stories of undocumented workers through body mapping. Toronto: Creative Commons, 2012.

GASTALDO, D.; MAGALHÃES, L.; CARRASCO, C. Mapas corporais narrados: um método para documentar trajetórias de saúde, resiliência, adoecimento e sofrimento. 
In: FRAGA, A. B.; CARVALHO, Y. M.; GOMES, I. M. As práticas corporais no campo da saúde. São Paulo: Hucitec, 2013. p. 83-100.

GOFFMAN, E. Estigma: notas sobre a manipulação da identidade deteriorada. Rio de Janeiro: LTC, 2008.

GUIMARÃES, A. S. A. Desigualdade e diversidade: os sentidos contrários da ação. In: BOTELHO, A.; SCWARCZ, L. M. (Org.). Cidadania, um projeto em construção: minorias, justiça e direitos. São Paulo: Claro Enigma, 2012. p. 38-47.

ISAY, R. A. Tornar-se gay: o caminho da auto-aceitação. São Paulo: Summus, 1998.

LOURO, G. L. (Org.). O corpo educado: pedagogias da sexualidade. Belo Horizonte: Autêntica, 2000.

MINAYO, M. C. O. O desafio do conhecimento: pesquisa qualitativa em saúde. São Paulo: Hucitec; Rio de Janeiro: Abrasco, 1999.

NOVAES, R. C. R. et al. (Org.). Politica Nacional de Juventude: diretrizes e perspectivas. São Paulo: Conselho Nacional de Juventude, 2006.

NUNAN, A. Homossexualidade e discriminação: o preconceito sexual internalizado. 2007. 390 f. Tese (Doutorado em Psicologia) - Pontifícia Universidade Católica do Rio de Janeiro, Rio de Janeiro, 2007.

NUNAN, A. Homossexualidade: do preconceito aos padrốes de consumo. Rio de Janeiro: Caravansarai, 2003.

PRADO, M. A. M.; JUNQUEIRA, R. D. Homofobia, hierarquização e humilhação social. In: VENTURI, G.; BOKANY, V. Diversidade sexual e homofobia no Brasil. São Paulo: Editora Fundação Perseu Abramo, 2011. p. 51-71.

RIOS, R. R. Homofobia na perspectiva dos direitos humanos e no contexto dos estudos sobre preconceito e dis- criminação. In: JUNQUEIRA, R. D. Diversidade sexual na educação: problematizaçóes sobre a homofobia nas escolas. Brasília: Ministério da Educação, 2009. p. 53-83.

RODRIGUES, J. C. O tabu do corpo. Rio de Janeiro: Achiamé, 1983.

SAGGESE, G. S. R. Quando o armário é aberto: visibilidade, percepçóes de risco e construção de identidades no coming out de homens homossexuais. 2009. 105 f. Dissertação (Mestrado em Saúde Coletiva) - Universidade do Estado do Rio de Janeiro, Rio de Janeiro, 2009.

SARACENO, B. Libertando identidades. Da reabilitação psicossocial à cidadania possível. Belo Horizonte: Te Corá; Rio De Janeiro: Instituto Franco Basaglia, 1999.

SEDGWICK, E. K. A epistemologia do armário. Cadernos Pagu, Campinas, n. 28, p. 19-54, 2007.

SEFFNER, F. Identidade de gênero, orientação sexual e vulnerabilidade social: pensando algumas situaçóes brasileiras. In: VENTURI, G.; BOKANY, V. Diversidade sexual e homofobia no Brasil. São Paulo: Editora Fundação Perseu Abramo, 2011. p. 39-50.

SOLOMON, J. Living with $X$ : a body mapping journal in the time of HIV and AIDS a facilitator's guide. Toronto: Creative Commons, 2007. Disponível em: <https:// sites.google.com/site/bodymaps/history>. Acesso em: 06 abr. 2015

VENTURI, G.; BOKANY, V. Síntese da pesquisa diversidade sexual e homofobia no Brasil: intolerância e respeito às diferenças sexuais. In: VENTURI, G.; BOKANY, V. Diversidade sexual e homofobia no Brasil. São Paulo: Editora Fundação Perseu Abramo, 2011. p. 189-251.

VIEIRA, A. J. Do altar para as ruas: luta, resistência e construção identitária de gays, lésbicas, bissexuais e transgêneros. Bagoas, Natal, v. 1, n. 2, p. 171-190, 2008.

\section{Contribuição dos Autores}

Aryel Murasaki responsabilizou-se pela concepção da pesquisa, revisão final do artigo, coleta e análise de dados e redação dos resultados. Sandra Galheigo foi responsável pela orientação, concepção da pesquisa e revisão final do artigo. Os autores aprovaram a versão final do texto.

\section{Fonte de Financiamento}

FAPESP - Processo no 2011/06623-4.

\section{Notas}

${ }^{1}$ A pesquisa foi aprovada pelo Comitê de Ética em Pesquisa da Faculdade de Medicina da Universidade de São Paulo sob o protocolo de pesquisa de número 145/11 em 13/05/2011. Os participantes assinaram o Termo de Consentimento Livre e Esclarecido e a autorização para uso de imagem dos desenhos produzidos.

${ }^{2}$ Segundo a Política Nacional de Juventude (NOVAES et al., 2006), os adolescentes-jovens estão na faixa etária de 15 a 17 anos; os jovens-jovens, de 18 a 24 anos; e os jovens adultos de 25 a 29 anos. 